\title{
Fragmentation of $\alpha$-Radical Cations of Arginine-Containing Peptides
}

\author{
Julia Laskin, ${ }^{\mathrm{a}}$ Zhibo Yang, ${ }^{\mathrm{a}}$ C. M. Dominic $\mathrm{Ng}^{\mathrm{b}}$ and Ivan K. Chu ${ }^{\mathrm{b}}$ \\ ${ }^{a}$ Chemical and Materials Sciences Division, Pacific Northwest National Laboratory, Richland, Washington, USA \\ ${ }^{b}$ Department of Chemistry, University of Hong Kong, Hong Kong, China
}

\begin{abstract}
Fragmentation pathways of peptide radical cations, $\mathrm{M}^{+}$, with well-defined initial location of the radical site were explored using collision-induced dissociation (CID) experiments. Peptide radical cations were produced by gas-phase fragmentation of $\mathrm{Co}^{\mathrm{III}}(\mathrm{salen})$-peptide complexes [salen $=N, N^{\prime}$-ethylenebis (salicylideneiminato)]. Subsequent hydrogen abstraction from the $\beta$-carbon of the side-chain followed by $\mathrm{C}_{\alpha}-\mathrm{C}_{\beta}$ bond cleavage results in the loss of a neutral side chain and formation of an $\alpha$-radical cation with the radical site localized on the $\alpha$-carbon of the backbone. Similar CID spectra dominated by radical-driven dissociation products were obtained for a number of arginine-containing $\alpha$-radicals, suggesting that for these systems radical migration precedes fragmentation. In contrast, proton-driven fragmentation dominates CID spectra of $\alpha$-radicals produced via the loss of the arginine side chain. Radicaldriven fragmentation of large $\mathrm{M}^{+\cdot}$ peptide radical cations is dominated by side-chain losses, formation of even-electron a-ions and odd-electron x-ions resulting from $\mathrm{C}_{\alpha}-\mathrm{C}$ bond cleavages, formation of odd-electron z-ions, and loss of the N-terminal residue. In contrast, charge-driven fragmentation produces even-electron y-ions and odd-electron b-ions. (J Am Soc Mass Spectrom 2010, 21, 511-521) @ 2010 American Society for Mass Spectrometry
\end{abstract}

G as-phase chemistry of odd-electron peptide ions is a growing area of research relevant to a variety of applications in biological mass spectrometry [1-8]. Radical chemistry plays an important role in gas-phase fragmentation of hydrogen-rich $[\mathrm{M}+$ $\mathrm{nH}]^{(\mathrm{n}-1)+\cdot}$ ions produced by capture of low-energy electrons by multiply protonated molecules or by electron-transfer processes $[1-5,9]$, hydrogen deficient radical anions $[\mathrm{M}-\mathrm{nH}]^{(\mathrm{n}-1)-}$ generated by electron detachment and photodetachment from multiply deprotonated molecules [10,11], peptides cationized on lithium [12], or transition metals [13-16], and $\mathrm{M}^{+}$. peptide radical cations. [In this study, we used standard notation for molecular radical cations, $\mathrm{M}^{+}$, which implies that the molecule has a charge and one unpaired electron, and specified the initial location of the radical site, when possible]. $\mathrm{M}^{+\cdot}$ ions can be produced via gas-phase fragmentation of specially designed precursors. For example, radical cations of peptides without additional $\mathrm{H}$ atoms are produced by collision-induced dissociation (CID) of ternary metal-ligand-peptide complexes [17-25]. In addition, $\mathrm{M}^{+\cdot}$ peptide ions have been generated through free radical-initiated reactions [26, 27], CID of nitrosopeptides [28], and peptides containing labile serine and homoserine nitrate esters [29], photolysis of peptides containing iodinated ty-

Address reprint requests to Dr. J. Laskin, Chemical and Materials Sciences Division, Pacific Northwest National Laboratory, P.O. Box 999 K-88, Richland, WA 99352, USA. E-mail: Julia.Laskin@pnl.gov rosine residues [30, 31], and photodissociation of protonated peptides [32, 33].

Fragmentation of small peptide radical cations has been recently reviewed [7, 34]. It is usually initiated by hydrogen abstraction or proton transfer from the initial radical site generated in the ion formation step [35, 36]. Reaction barriers for $\mathrm{H}$ atom transfer in several small model radicals have been reported by Moran et al. [37]. They demonstrated that in the absence of side chains 1,4 $[\mathrm{C} \leftrightarrow \mathrm{C}]$ hydrogen transfer along the peptide backbone is associated with substantial barriers of ca. $100 \mathrm{~kJ} / \mathrm{mol}$, while 1,5 and 1,6 [C↔N] hydrogen shifts from $\mathrm{N}$ centered radicals to $\mathrm{C}$-centered radicals are exothermic and associated with much lower barriers of ca. 40-60 $\mathrm{kJ} / \mathrm{mol}$. These results suggest that C-centered $\alpha$ radicals play a major role in gas-phase chemistry of $\mathrm{M}^{+}$. peptide ions. In addition, $\alpha$-radical cations are important intermediates in secondary fragmentation of $[\mathrm{M}+$ $\mathrm{nH}]^{(\mathrm{n}-1)+\cdot}$ ions produced by electron capture or electrontransfer. O'Connor and coworkers demonstrated that the initial electron capture produces $\alpha$-carbon peptide radicals. The radical site is subsequently transferred to other locations on the backbone, resulting in side-chain losses and multiple backbone cleavages [38].

Radical mobility in peptide ions with well-defined initial radical site has been recently studied by several groups. Wee et al. compared dissociation of sodiated $\alpha$-radicals produced through gas-phase fragmentation of nitrate esters of N-benzoyl- $\alpha$-methylserylglycine [29]. They found that fragmentation of such radical precursors is independent of the initial radical location and 
suggested that hydrogen migration precedes fragmentation in these small model systems. Wesdemiotis and coworkers showed that isomeric $\alpha$-radical cations of diglycine formed by CID of lithiated dipeptides are separated by a high-energy isomerization barrier [39]. Fragmentation of $\alpha$-radical cations of GGG was examined by Chu et al. using CID and DFT calculations of the structures and energetics of different radical species and the corresponding isomerization barriers [40]. They demonstrated that the radical sites in $\mathrm{GGG}^{+}, \mathrm{GGG}^{+}$, and $\mathrm{GGG}^{+} \alpha$-radical cations are rather immobile with isomerization barriers exceeding $44.7 \mathrm{kcal} / \mathrm{mol}(>187$ $\mathrm{kJ} / \mathrm{mol}$ ). As a result, CID spectra of the three triglycine $\alpha$-radicals are distinctly different. Julian and coworkers observed differences in fragmentation behavior of several more complex $\alpha$-radical peptides [41], while Zhang and Reilly reported similar fragmentation behavior for a number of $\left[\mathrm{a}_{\mathrm{n}}+\mathrm{H}\right]^{+\cdot}$ ions, in which the radical is initially positioned at the C-terminal $\alpha$-carbon [42]. Recently, we examined the energetics and dynamics of dissociation of an $\alpha$-radical produced by the loss of p-quinomethide from DRVYIHPF ${ }^{+\cdot}$ [43]. We found that backbone fragmentation of this radical cation is dominated by cleavages at positions remote from the initial radical site suggesting that the radical site in this peptide is relatively mobile.

Dissociation of peptide radical cations is strongly influenced by the competition between charge-driven and radical-driven bond cleavages [7, 34-36]. Because of the favorable energetics and dynamics of proton transfer along the peptide backbone, charge-driven fragmentation plays an important role in dissociation of di- and tripeptides lacking basic residues [35, 36, 40]. In contrast, because proton-driven fragmentation of arginine-containing peptides is associated with the substantial kinetic shift [44], larger peptides containing the basic arginine residue predominantly undergo radicaldriven fragmentation [45]. Charge-driven fragmentation of peptide radicals results in formation of oddelectron $\left[b_{n}-H\right]^{+}$and even-electron $y_{n}$ ions while radical-driven processes favor side-chain losses and $\mathrm{C}_{\alpha}-\mathrm{C}$ bond cleavages. As a result, fragmentation of relatively large peptide radicals with arginine at the $\mathrm{N}$-terminus is often dominated by the formation of $\mathrm{a}_{\mathrm{n}}$ ions [41]. In addition, c-ions are formed at serine and threonine residues $[41,42]$ and $c / z$ ions are formed at tryptophan and tyrosine [46]. While the formation of $a_{n}$ ions has received significant attention in the literature, other dissociation pathways of peptide radical cations have been generally described only for di- and tripeptides [34-36, 40,46]. In this study we present a more detailed description of the fragmentation behavior of large peptide radical cations. We examine the effect of the initial location of the radical site and the presence and position of the basic residue on the observed dissociation pattern. Loss of neutral side chains is used to generate odd-electron peptide ions with well-defined initial location of the radical site in different positions along the peptide backbone.

\section{Experimental}

\section{Chemicals}

All chemicals and reagents were commercially available (Sigma-Aldrich, St. Louis, MO, USA). Angiotensin III (RVYIHPF) was purchased from Sigma-Aldrich, while all other peptides were purchased from the American Peptide Company (Sunnyvale, CA, USA). Cobalt(III)salen complex [salen $=N, N^{\prime}$-ethylenebis (salicylideneiminato)] was synthesized following the procedure described elsewhere [47]. Several peptides were synthesized according to literature procedures. Fmocprotected amino acids and the Wang resin were purchased from Advanced ChemTech (Louisville, KY, USA). Samples typically comprised $60 \mu \mathrm{M}$ metal complex and $5 \mu \mathrm{M}$ peptide in a 50:50 (vol:vol) water/ methanol solution.

\section{Mass Spectrometry}

Fragmentation of peptide radical cations was examined using an ion trap mass spectrometer (LCQ; ThermoFinnigan, San Jose, CA, USA) and an LTQ (linear ion trap)/Orbitrap Hybrid Mass Spectrometer (Thermo Electron Corporation, Bremen, Germany) equipped with an electrospray ionization (ESI) source. In LCQ experiments, samples were continuously infused at a rate of $5 \mu \mathrm{L} / \mathrm{min}$ into the pneumatically assisted electrospray probe using air as the nebulizer gas. In LTQ/ Orbitrap experiments samples were injected through a pulled fused silica capillary tip (50 $\mu \mathrm{m}$ ID) at a flow rate of $0.3-0.5 \mu \mathrm{L} / \mathrm{min}$ using a spray voltage of $4 \mathrm{kV}$. Peptide radical cations, $\mathrm{M}^{+}$, were generated by insource CID of the corresponding positively charged $\left[\mathrm{Co}^{\mathrm{III}} \text { (salen)-M }\right]^{+}$complexes.

LTQ/Orbitrap $\mathrm{MS}^{n}$ experiments were performed using multiple stages of mass isolation and CID in the LTQ followed by high-resolution mass analysis of the resulting fragment ions in the Orbitrap. Isolation windows of 3-5 Da for the $\left[\mathrm{Co}^{\mathrm{III}}-\text { salen)M }\right]^{+}$complex and 1-2 Da for radical cations were used consistently in all experiments; these conditions allowed us to maximize the $\mathrm{MS}^{n}$ signal and eliminate interferences from adjacent peaks. Unit mass resolution was utilized for all LCQ experiments. The isolation width had no significant influence of the relative abundance of peaks in $\mathrm{MS}^{n}$ spectra as long as interferences were eliminated (e.g., $[\mathrm{M}+\mathrm{H}]^{+}$peak adjacent to the $\mathrm{M}^{+\cdot}$ peak). Furthermore, we note that similar $\mathrm{MS}^{n}$ spectra were obtained for systems studied using both the LCQ and LTQ/Orbitrap instruments suggesting that isolation conditions had no significant effect on the results presented in this paper. The collision energy was adjusted to obtain efficient fragmentation of the precursor ion. The system was operated with a resolving power of $60,000(\mathrm{~m} / \Delta \mathrm{m}$ at $400 \mathrm{Da}$ ). Fragment ions were unambiguously identified based on the accurate mass measurement. 


\section{Results and Discussion}

\section{Side-Chain Losses and Formation of $\alpha$-Radicals}

Loss of stable molecules or radical species from peptide side chains is one of the major dissociation pathways of odd-electron peptide ions in the gas phase. Common side-chain losses observed for a series of peptide radical cations examined in this work and previous studies [7, 15, 35, 41, 42, 45, 48] are listed in Table 1. Mechanisms of side-chain losses shown in Scheme $\mathbf{1}$ have been discussed in the literature $[19,35,41]$. Hydrogen abstraction from the $\gamma$-carbon of the side chain (reaction 1) followed by $\mathrm{C}_{\alpha}-\mathrm{C}_{\beta}$ bond cleavage results in the loss of the entire side-chain as a stable neutral molecule and formation of peptide $\alpha$-radical cation. Loss of the neutral side chain can be used for generating peptide radical cations with well-defined initial radical location; loss of $\mathrm{CO}_{2}$ from the $\mathrm{C}$-terminal carboxyl group produces an $\alpha$-radical on the $\mathrm{C}$-terminal amino acid residue. Alternatively, $\mathrm{C}_{\beta}-\mathrm{C}_{\gamma}$ bond cleavage followed by the loss of a small radical species from the side chain is observed (reaction 2). This dissociation pathway results in formation of an even-electron fragment ions that is typically much more stable towards fragmentation than the corresponding odd-electron ion [49].

Several recent studies by this and other groups have examined the energetics, dynamics, and mechanisms of fragmentation of peptide $\alpha$-radicals [40, 43]. This work provides the first detailed account of the fragmentation behavior of peptide $\alpha$-radical cations produced by the loss of neutral side chains from $\mathrm{M}^{+\cdot}$ ions of model peptides containing at least one basic residue $(\mathrm{H}, \mathrm{K}$, or $\mathrm{R})$ and a tyrosine $(\mathrm{Y})$ or tryptophan $(\mathrm{W})$ residue. Peptide radical cations were produced through gas-phase fragmentation of ternary [Co ${ }^{\text {III }}$ (salen)-peptide $]^{+}$complexes generated in the ESI source (Scheme 2, reactions 1 and 2). (We note parenthetically that while the prop- erties of the metal and the organic ligand can be tuned to generate radical cations of aliphatic peptides [21], the presence of $\mathrm{Y}, \mathrm{W}$, and basic residues in peptide sequence facilitate the formation of $\mathrm{M}^{+\cdot}$ ions [17-23].) In this study, peptide $\alpha$-radicals were produced either directly by collision-induced dissociation (CID) of the $\left[\mathrm{Co}^{\mathrm{III}} \text { (salen)-peptide }\right]^{+}$ion or by sequential fragmentation of isolated $\mathrm{M}^{+\cdot}$ ions. CID spectra of $\alpha$-radical cations were rather independent of the details of their formation suggesting that in most cases radical cations produced directly from the complex and through subsequent fragmentation of the $\mathrm{M}^{+\cdot}$ ion have similar structures.

\section{Fragmentation Spectra of Peptide $\alpha$-Radical Cations}

In this study, we examined fragmentation behavior of a number of peptides containing basic arginine, lysine and histidine residues located at or close to C- and $\mathrm{N}$-termini of the peptide. We present several examples of the characteristic fragmentation behavior observed for a variety of peptide sequences. Specifically, we selected peptide sequences that generated a number of different $\alpha$-radicals including the $\alpha$-radical cation produced by the loss of the basic side-chain. Because loss of the entire lysine side chain was only observed when arginine was present in the sequence and the histidine side chain is eliminated as the $\mathrm{C}_{4} \mathrm{H}_{5} \mathrm{~N}_{2}$ radical species resulting in formation of stable even-electron fragment ion, the examples shown in this study are limited to arginine-containing peptides. Figures 1, 2, 4, 5, and Supplementary Figure S1, (which can be found in the electronic version of this article), show representative MS/MS spectra obtained for $\alpha$-radical cations of argininecontaining peptides.

Table 1. Observed neutral losses from peptide radical cations

\begin{tabular}{|c|c|c|c|c|}
\hline Amino acid residue & Radical loss & MW & Neutral molecule loss & MW \\
\hline Ala (A) & $\mathrm{CH}_{3}^{\bullet}$ & 15.02347 & & \\
\hline $\operatorname{Ser}(S)$ & $\mathrm{OH}^{\circ}$ & 17.00274 & $\mathrm{CH}_{2} \mathrm{O}$ & 30.01056 \\
\hline Ile (I) & $\mathrm{C}_{2} \mathrm{H}_{5}^{\bullet}$ & 29.03912 & $\mathrm{C}_{4} \mathrm{H}_{8}$ & 56.0626 \\
\hline Leu (L) & $\mathrm{C}_{3} \mathrm{H}_{7}^{\bullet}$ & 43.05477 & $\mathrm{C}_{4} \mathrm{H}_{8}$ & 56.0626 \\
\hline Asp (D) & $\mathrm{COOH}^{\bullet}$ & 44.99765 & $\mathrm{CO}_{2}$ & 43.98983 \\
\hline \multirow[t]{2}{*}{ Met (M) } & $\mathrm{CH}_{3} \mathrm{~S}^{\bullet}$ & 46.99555 & $\mathrm{C}_{3} \mathrm{H}_{6} \mathrm{~S}$ & 74.01902 \\
\hline & $\mathrm{C}_{2} \mathrm{H}_{5} \mathrm{~S}^{\bullet}$ & 61.0112 & & \\
\hline$G \ln (Q)$ & $\mathrm{NH}_{2} \mathrm{COCH}_{2}^{\bullet}$ & 58.02929 & $\mathrm{NH}_{2} \mathrm{COC}_{2} \mathrm{H}_{4}$ & 71.03711 \\
\hline Lys (K) & $\mathrm{C}_{3} \mathrm{H}_{8} \mathrm{~N}^{\bullet}$ & 58.06567 & $\mathrm{C}_{4} \mathrm{H}_{9} \mathrm{~N}$ & 71.0735 \\
\hline Glu (E) & $\mathrm{CH}_{3} \mathrm{COO}^{\bullet}$ & 59.0133 & $\mathrm{C}_{2} \mathrm{H}_{4} \mathrm{COO}$ & 72.02113 \\
\hline $\mathrm{His}(\mathrm{H})$ & $\mathrm{C}_{4} \mathrm{H}_{5} \mathrm{~N}_{2}^{\bullet}$ & 81.04527 & & \\
\hline \multirow[t]{2}{*}{$\operatorname{Arg}(\mathrm{R})$} & $\mathrm{C}_{2} \mathrm{H}_{6} \mathrm{~N}_{3}^{\bullet}$ & 72.05617 & $\mathrm{C}_{3} \mathrm{H}_{9} \mathrm{~N}_{3}$ & 87.07964 \\
\hline & $\mathrm{C}_{3} \mathrm{H}_{8} \mathrm{~N}_{3}^{\bullet}$ & 86.07182 & $\mathrm{C}_{4} \mathrm{H}_{9} \mathrm{~N}_{3}$ & 99.07964 \\
\hline $\operatorname{Tyr}(\mathrm{Y})$ & & & $\mathrm{C}_{7} \mathrm{H}_{6} \mathrm{O}$ & 106.0418 \\
\hline Trp (W) & & & $\mathrm{C}_{9} \mathrm{H}_{7} \mathrm{~N}$ & 129.0578 \\
\hline $\mathrm{N}$-terminus amidated $\mathrm{C}$-terminus & $\mathrm{NH}_{2}^{\bullet}$ & 16.01872 & & \\
\hline C-terminus & $\mathrm{COOH}^{\bullet}$ & 44.99765 & $\mathrm{CO}_{2}$ & 43.98983 \\
\hline Other & & & $\mathrm{NH}_{3}, \mathrm{H}_{2} \mathrm{O}$ & \\
\hline
\end{tabular}


<smiles>[R]C=CCC(CCC)C(C)=O</smiles><smiles>[R]CC(CC)[C@H](C)N([CH])CC</smiles>

Scheme 1
1)

\section{Radical Mobility}

Figure 1 presents $\mathrm{MS}^{4}$ spectra obtained for several $\alpha$-radical cations of angiotensin III (RVYIHPF). Specifically, panel a shows the spectrum obtained for the C-terminal $\alpha$-radical produced by the loss of $\mathrm{CO}_{2}$ from the carboxyl group, $\left[\mathrm{M}-\mathrm{CO}_{2}\right]^{+}$, panel b shows dissociation behavior of the $\alpha$-radical located on the fourth residue, $[\mathrm{M}-56]^{+}$, and panel $\mathrm{c}$ shows the spectrum obtained for the $\alpha$-radical located on the third residue generated via the loss of p-quinomethide from tyrosine, $[\mathrm{M}-106]^{+\cdot}$. Remarkably, similar $\mathrm{MS}^{4}$ spectra dominated by side-chain losses and a-ion formation were obtained for $\left[\mathrm{M}-\mathrm{CO}_{2}\right]^{+\cdot},[\mathrm{M}-106]^{+\cdot}$, and $[\mathrm{M}-56]^{+}$. ions, suggesting that fragmentation behavior of peptide radical cations is rather insensitive to small variations in the sequence. Furthermore, fragmentation spectra obtained for these $\alpha$-radicals closely resemble the CID spectrum of the $\mathrm{M}^{+\cdot}$ ion of angiotensin III [45]. Similar results were obtained for all arginine-containing $\alpha$ radical cations examined in this study. While the overall fragmentation behavior depends on the peptide sequence, slight changes in the sequence originating from the loss of the non-basic side chain have little effect on the observed fragments.

Similar fragmentation patterns observed for $\alpha$-radical cations containing arginine (Figures 1, 2, 5, Supplementary Figure S1) indicate that efficient interconversion between different isomers via hydrogen atom transfer precede radical-induced fragmentation of these species. These results are consistent with our previous work showing that fragmentation of the DRVG IHPF ${ }^{+}$ $\alpha$-radical cation is dominated by bond cleavages that are remote from the initial position of the radical site

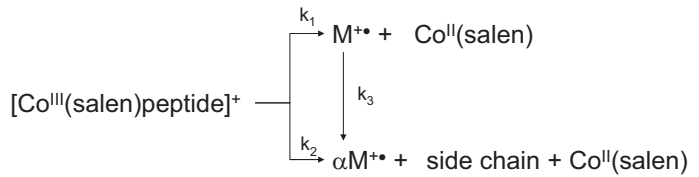

[43] and with the results reported by Julian and coworkers [41] and Reilly and coworkers [42].

Dissociation of peptide radical cations with the $\mathrm{N}$ terminal arginine residue is commonly dominated by $\mathrm{C}_{\alpha}-\mathrm{C}$ bond cleavages resulting in formation of evenelectron a-ions. Several groups examined mechanisms of a-ion formation from such precursors. The proposed mechanism shown in Scheme 3 involves hydrogen abstraction from the $\beta$-carbon of the corresponding side chain followed by dissociation of the backbone $[26,36$,

$[\mathrm{RVYIHPF}]^{+}-\mathrm{CO}_{2}$

(a)

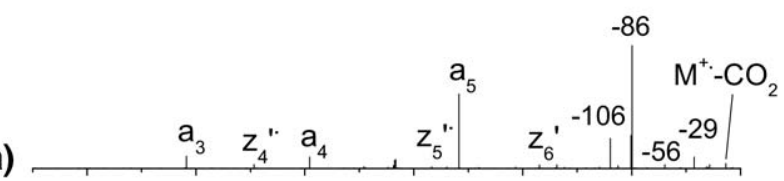

RVYG'HPF $^{+}$

(b)

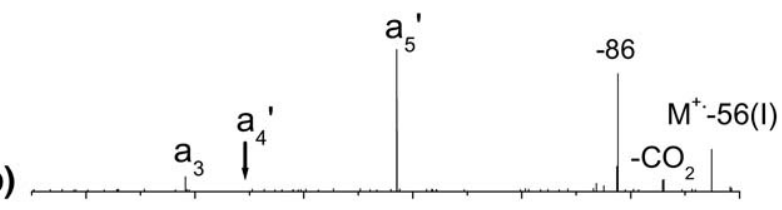

(c)

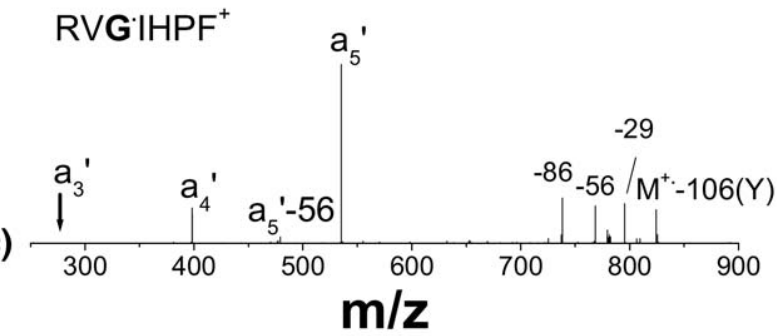

Figure 1. LTQ/Orbitrap $\mathrm{MS}^{4}$ spectra of $\alpha$-radical cations of angiotensin III (RVYIHPF) produced by the loss of (a) C-terminal $\mathrm{CO}_{2}$, (b) $\mathrm{C}_{4} \mathrm{H}_{8}$ (56) of isoleucine, and (c) $\mathrm{C}_{7} \mathrm{H}_{6} \mathrm{O}$ (106) of tyrosine from the $\mathrm{M}^{+*}$ precursor ion. Fragment ions shifted by the mass of the corresponding side chain are marked with apostrophes. The predicted locations of the missing $\mathrm{a}_{4}^{\prime}$ ion in panel $\mathrm{b}$ ) and $\mathrm{a}_{3}^{\prime}$ ion in panel (c) are marked with arrows. 
(a)

\section{G.VYIHPR}

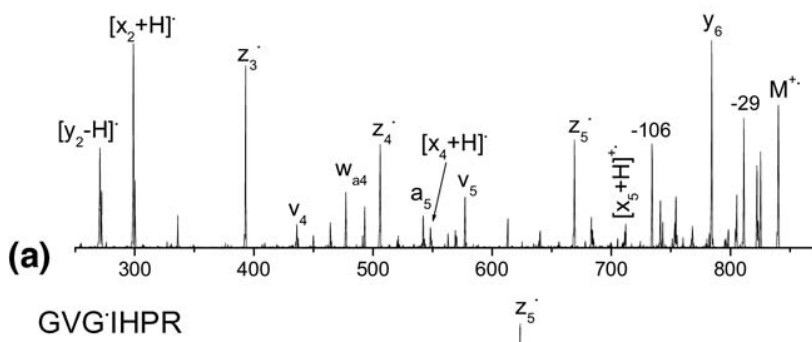

(b)

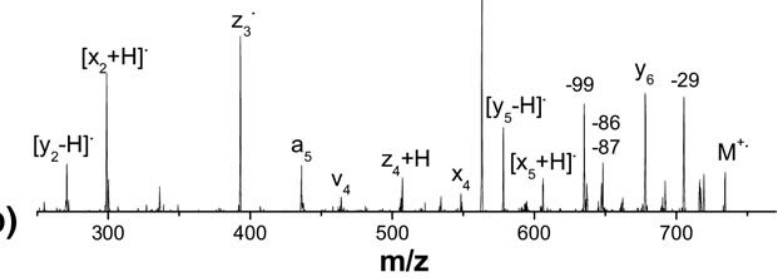

Figure 2. Ion trap CID spectra of the (a) G VYIHPR ${ }^{+}$and (b) GVGIHPR $^{+}$.

45]. According to this mechanism, peptide radical cation is a distonic ion in which the basic arginine residue is protonated while the radical site is located elsewhere on the peptide. Abstraction of the $\beta$-hydrogen of the side chain is followed by $\mathrm{C}_{\alpha}-\mathrm{C}$ bond cleavage. Recently, deuterium labeling experiments conducted by Julian and coworkers unambiguously demonstrated that abstraction of the $\beta$-hydrogen precedes backbone fragmentation resulting in a-ion formation [41]. Furthermore, they showed that $\mathrm{C}_{\alpha}-\mathrm{C}$ bond cleavage in peptide radical cations does not occur on glycine and the cleavage propensity increases for side chains with lower $\mathrm{C}_{\beta}-\mathrm{H}$ bond dissociation energy (e.g., Trp, Thr, His, Phe, and Tyr). Based on the above discussion, it is reasonable to assume that efficient interconversion between different $\alpha$-radicals observed in this study is facilitated by the presence of side chains containing $\beta$-hydrogen atoms. In contrast, high isomerization barriers reported by $\mathrm{Chu}$ et al. for GGG $\alpha$-radical cations [40] reflect the intrinsic behavior of the peptide backbone in the absence of complex side chains.

Formation of $\left[x_{n}+H\right]^{+\cdot}$ and $z_{n}^{+\cdot}$ Ions

The mechanism of the $\mathrm{C}_{\alpha}-\mathrm{C}$ bond cleavage shown in Scheme 3 suggests that a-ion formation is favorable in the presence of a basic residue at the $\mathrm{N}$-terminus, while $\left[\mathrm{x}_{\mathrm{n}}+\mathrm{H}\right]^{+\cdot}$-ions should be predominantly formed when the charge is localized on the C-terminus. While odd- electron $\left[\mathrm{x}_{\mathrm{n}}+\mathrm{H}\right]^{+\cdot}$ ions are rarely observed in MS/MS spectra, they have been identified as possible precursors of $\mathrm{v}_{\mathrm{n}}$ fragments in high-energy CID of protonated peptides [50]. More recently, the formation of these ions via the homolytic $\mathrm{C}_{\alpha}-\mathrm{C}$ bond cleavage followed by fast fragmentation was used to rationalize $157 \mathrm{~nm}$ photodissociation of $[\mathrm{M}+\mathrm{H}]^{+}$peptide ions [32] and the formation of odd-electron z-ions in MS/MS spectra of peptide radical cations produced in photodissociation experiments. Sun et al. suggested that these radical species are very unstable and immediately fragment into $z_{n}^{+-}$-ions (reaction 3) [41], while Reilly and coworkers suggested that $\left[\mathrm{x}_{\mathrm{n}}+\mathrm{H}\right]^{+\cdot}$ ions lose hydrogen to form even-electron x-ions (reaction 4) [32]. Oddelectron $\mathrm{x}$-ions have been previously observed in MS/MS spectra of peptide radical cations produced via gasphase redox chemistry [45, 51, 52] However, their formation has not been discussed in any detail.

$$
\begin{aligned}
& {\left[\mathrm{x}_{\mathrm{n}}+\mathrm{H}\right]^{+\cdot} \rightarrow \mathrm{z}_{\mathrm{n}}^{+\cdot}+\mathrm{NH}=\mathrm{C}=\mathrm{O}} \\
& {\left[\mathrm{x}_{\mathrm{n}}+\mathrm{H}\right]^{+\cdot} \rightarrow \mathrm{x}_{\mathrm{n}}^{+}+\mathrm{H}^{\cdot}}
\end{aligned}
$$

MS/MS spectra of GVGIHPR ${ }^{+}$and GVYIHPR ${ }^{+}$shown in Figure 2 contain a number of $\left[\mathrm{x}_{\mathrm{n}}+\mathrm{H}\right]^{+\cdot}(n=2,3,5)$ fragment ions (see Supporting Information for detailed peak assignment). Table 2 summarizes the observed intensities of a-, z-, and x-type ions for a number of $\alpha$-radical cations with arginine at the $\mathrm{C}$-terminus. Formation of $\left[\mathrm{x}_{\mathrm{n}}+\mathrm{H}\right]^{+\cdot}$ ions is clearly observed for all precursor ions with the C-terminal arginine examined in this study.

In addition, z-ions are abundant in spectra of peptide radicals with the $\mathrm{C}$-terminal arginine residue. Oddelectron z-ions could be formed from unstable $\left[\mathrm{x}_{\mathrm{n}}+\right.$ $\mathrm{H}]^{+\cdot}$ precursors (reaction 3) [41]. Preliminary results from this group show that some $\left[x_{n}+\mathrm{H}\right]^{+\cdot}$ ions dissociate almost exclusively through reaction 3 while other predominantly form smaller odd-electron $\mathrm{x}$-ions upon collisional activation. Figure 3 shows an $\mathrm{MS}^{4}$ spectrum of the $\left[\mathrm{x}_{5}+\mathrm{H}\right]^{+\cdot}$ ion of GVGIHPR ${ }^{+}$. Similar spectra were obtained for this fragment ion generated from a number of precursors. The dominant $z_{3}^{+\cdot}$ fragment is most likely produced by sequential fragmentation of the $\left[\mathrm{x}_{5}+\mathrm{H}\right]^{+\cdot}$ ion. In addition, loss of two and three N-terminal residues from $\left[\mathrm{x}_{5}+\mathrm{H}\right]^{+\cdot}$ results in formation of smaller $\left[\mathrm{x}_{3}+\mathrm{H}\right]^{+\cdot}$ and $\left[\mathrm{x}_{2}+\mathrm{H}\right]^{+\cdot}$ oddelectron $\mathrm{x}$-ions. However, loss of $\mathrm{NH}=\mathrm{C}=\mathrm{O}$ resulting in formation of the $z_{5}^{+\cdot}$ ion (reaction 3) is only a minor channel in the MS ${ }^{4}$ spectrum of the $\left[\mathrm{x}_{5}+\mathrm{H}\right]^{+\cdot}$ ion. Likely, dissociation of the transient $\left[\mathrm{x}_{5}+\mathrm{H}\right]^{+\cdot}$ ion

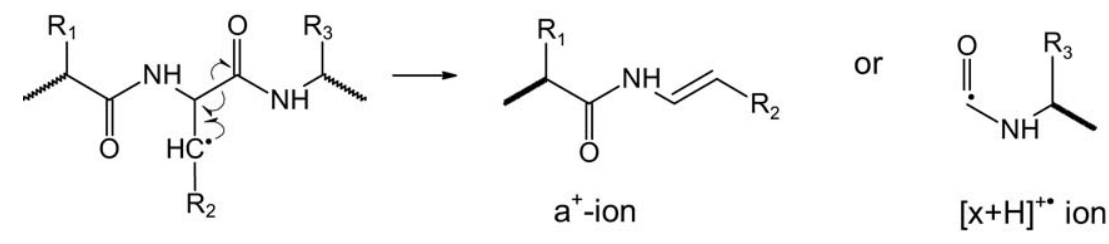

Scheme 3 
Table 2. Abundance of a-, $\mathrm{x}^{-}$, and $\mathrm{z}$-type ions observed for several $\alpha$-radical cations normalized to the most abundant peak in the spectrum

\begin{tabular}{|c|c|c|c|}
\hline & a-Ions & $x$-Ions & z-Ions \\
\hline \multirow[t]{5}{*}{$\mathrm{GVYG}^{\bullet} \mathrm{HPR}^{+}$} & $\begin{array}{c}a_{5}-H(28 \%) \\
a_{5}(20 \%)\end{array}$ & $\mathrm{x}_{2}+\mathrm{H}(95 \%)$ & - \\
\hline & - & $x_{3}(10 \%)$ & $z_{3}(8 \%)$ \\
\hline & - & $x_{4}+H(15 \%)$ & $z_{4}(98 \%)$ \\
\hline & - & $x_{5}+H(30 \%)$ & $z_{5}(50 \%)$ \\
\hline & - & $x_{6}(4 \%)$ & $z_{6}(20 \%)$ \\
\hline \multirow[t]{5}{*}{$\mathrm{GVG}^{\bullet} \mathrm{IHPR}^{+}$} & $a_{5}(20 \%)$ & $x_{2}+H(55 \%)$ & - \\
\hline & - & - & $z_{3}(75 \%)$ \\
\hline & - & $x_{4}(9 \%)$ & $\mathrm{z}_{4}+\mathrm{H}(15 \%)$ \\
\hline & - & $x_{5}+H(15 \%)$ & $z_{5}(100 \%)$ \\
\hline & - & & $z_{6}(6 \%)$ \\
\hline \multirow[t]{5}{*}{ WVG $^{\bullet}{ }^{\prime H P R}{ }^{+}$} & - & $x_{2}+H(25 \%)$ & - \\
\hline & - & $x_{3}+H(15 \%)$ & $z_{3}(48 \%)$ \\
\hline & - & $x_{4}(5 \%)$ & $\mathrm{z}_{4}+\mathrm{H}(12 \%)$ \\
\hline & - & $x_{5}+H(5 \%)$ & $z_{5}(100 \%)$ \\
\hline & - & $x_{6}+H(6 \%)$ & $z_{6}(20 \%)$ \\
\hline
\end{tabular}

formed during the $\mathrm{C}_{\alpha}-\mathrm{C}$ bond cleavage competes with radical migration to a more favorable site. As a result, the $\left[\mathrm{x}_{5}+\mathrm{H}\right]^{+\cdot}$ ion used in our MS ${ }^{4}$ experiments may have a different structure that does not readily form the $\mathrm{z}_{5}^{+}$fragment upon collisional activation. Although the abundant $\mathrm{z}_{5}^{+\cdot}$ fragment observed in $\mathrm{MS}^{3}$ spectra of peptides with the C-terminal arginine residue (Figure 2 and Table 2) may be produced predominantly from the transient $\left[\mathrm{x}_{5}+\mathrm{H}\right]^{+\cdot}$ precursor, a different mechanism discussed below could be responsible for the observed $\mathrm{N}-\mathrm{C}_{\alpha}$ bond cleavage.

It should be noted that the enhanced formation of $z$-ions at tyrosine and valine was observed for several peptide ions regardless of the presence and position of the basic amino acid residue. For example, spectra of $\alpha$-radicals lacking the arginine residue shown in Figure 4 contain fairly abundant $\mathrm{z}_{4}^{+\cdot}$ and $\mathrm{z}_{5}^{+\cdot}$ fragments, while minor $z_{4}^{+\cdot}, z_{5}^{+}$, and $z_{6}^{+\cdot}$ fragments were observed for RVYIHPF radicals (Figure 1). The $\mathrm{z}_{5}^{+\cdot}$ ion is a major fragment in MS/MS spectra of $\mathrm{GVG}^{\mathrm{IHPR}}{ }^{+}$and WVGIHPR $^{+}$(Table 2), while GVYGHPR ${ }^{+}$preferen-

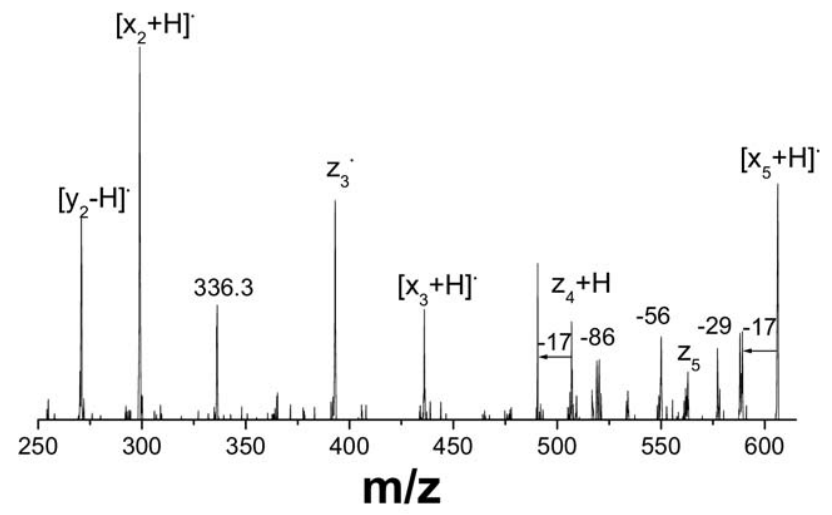

Figure 3. Ion trap $\mathrm{MS}^{4}$ spectrum of the $\left[\mathrm{x}_{5}+\mathrm{H}\right]^{+\cdot}$ fragment of $\mathrm{GVG}^{\mathrm{IHPR}}{ }^{+}$.

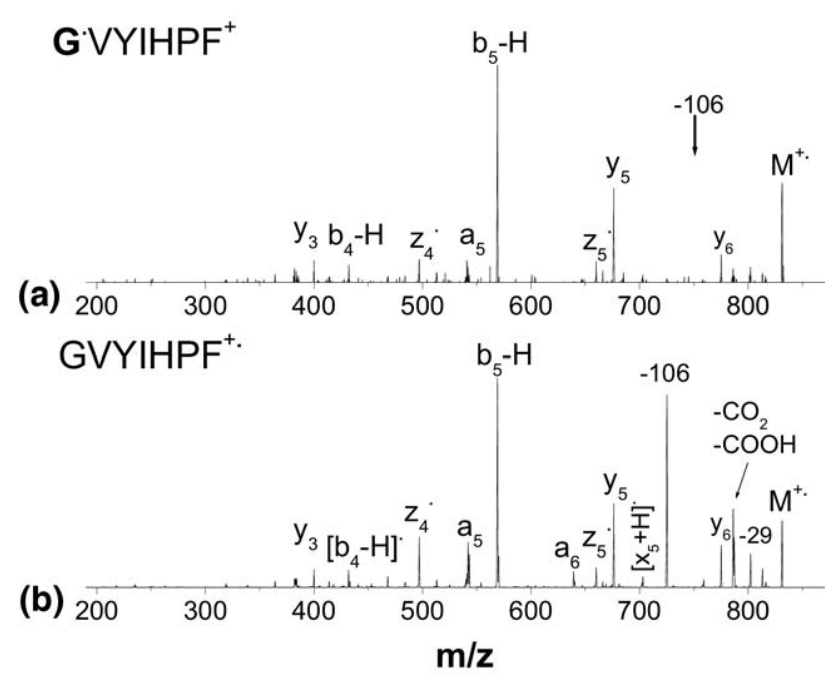

Figure 4. Ion trap CID spectra of the (a) $\alpha$-radical cation $\mathrm{G}$ VYIHPF $^{+}$produced by the loss of $\mathrm{C}_{4} \mathrm{H}_{9} \mathrm{~N}_{3}$ (99) of arginine from RVYIHPF; (b) the corresponding radical cation produced through reaction 1.

tially forms the $\mathrm{z}_{4}^{+\cdot}$ fragment ion. While in the presence of the C-terminal arginine residue z-ions are likely formed through consecutive fragmentation of oddelectron $x$-ions, a different mechanism is required to rationalize the formation of $z$-ions for peptides with the N-terminal arginine. Siu and coworkers presented a detailed discussion of the formation of z-ions from diand tripeptides containing tyrosine and tryptophan residues [46]. They demonstrated that the reaction mechanism involves proton transfer from the $\beta$-carbon of tryptophan or tyrosine to the carbonyl oxygen of the amide group, followed by cleavage of the $\mathrm{N}-\mathrm{C}_{\alpha}$ bond. A similar mechanism is most likely responsible for direct formation of z-ions from larger $\mathrm{M}^{+\cdot}$ ions.

\section{Suppression of the $C_{\alpha}-C$ Bond Cleavage at the Radical Site}

One notable difference between spectra of $\alpha$-radicals shown in Figures 1, 2, 4, and 5 originates from suppression of a-ion and [x $+\mathrm{H}]$-ion formation at the $\alpha$-radical site. For example, the $a_{3}$ ion is not formed from the [M -106$]^{+\cdot}$ ion of RVYIHPF (the location of this fragment in Figure 1c is marked with an arrow), in which the radical is initially located at the third residue. Similarly, the $\mathrm{a}_{4}$ ion is strongly suppressed in the spectrum of the RVYGHPF ${ }^{+}$ion (Figure 1b), in which the radical is located on the $\alpha$-carbon of the fourth residue and the $\mathrm{a}_{8}^{+}$ion in the spectrum of the RPKPQQFGGLM-NH ${ }_{2}^{+}$precursor (Figure 5e).

Similarly, formation of $\left[\mathrm{x}_{\mathrm{n}}+\mathrm{H}\right]^{+\cdot}$ fragments is strongly suppressed at the radical site. Instead, evenelectron $\mathrm{x}$-ions are formed nominally corresponding to the $\mathrm{C}_{\alpha}-\mathrm{C}$ bond cleavage at the radical site. Efficient suppression of backbone fragmentation at the radical site observed for a variety of peptide $\alpha$-radicals is 


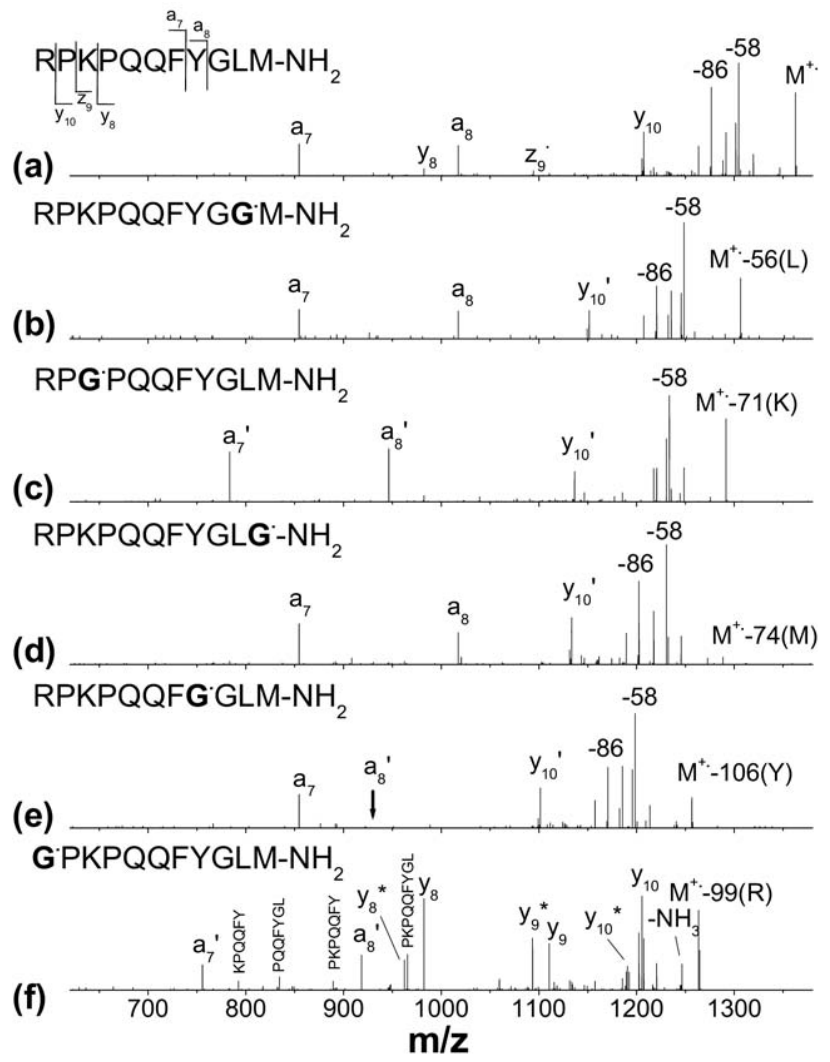

Figure 5. LTQ/Orbitrap $\mathrm{MS}^{3}$ spectrum of (a) the $\mathrm{M}^{+\cdot}$ ion of Tyr ${ }^{8}$-Substance $\mathrm{P}$ (RPKPQQFYGLM-NH ${ }_{2}$ ) and $\mathrm{MS}^{4}$ spectra of $\alpha$-radical cations produced by the loss of (b) $\mathrm{C}_{4} \mathrm{H}_{8}$ (56) of isoleucine, (c) $\mathrm{C}_{4} \mathrm{H}_{9} \mathrm{~N}$ (71) of lysine, (d) $\mathrm{C}_{3} \mathrm{H}_{6} \mathrm{~S}$ (74) of methionine, (e) $\mathrm{C}_{7} \mathrm{H}_{6} \mathrm{O}$ (106) of tyrosine, and (f) $\mathrm{C}_{4} \mathrm{H}_{9} \mathrm{~N}_{3}$ (99) of arginine. Fragment ions shifted by the mass of the corresponding side-chain are marked with apostrophes. The predicted location of the missing $\mathbf{a}_{8}^{\prime}$ ion in panel (e) is marked with an arrow.

consistent with the mechanism of $\mathrm{C}_{\alpha}-\mathrm{C}$ bond cleavage discussed earlier (Scheme 3) [41].

Formation of $x_{n}^{+}$Ions

Formation of even-electron $\mathrm{x}$-ions and odd-electron a-ions from peptide radical cations has not been previously discussed. Table 2 lists a number of these fragments observed in CID spectra of peptide radicals with arginine at the C-terminus. Even-electron $\mathrm{x}$-ions and odd-electron a-ions are commonly observed in EDD spectra of hydrogen-deficient peptide radical anions. Zubarev and coworkers suggested that these fragments are produced from nitrogen-centered radical species as shown in Scheme 4 [10]. Ab initio calculations reported by Simons and coworkers demonstrated that the formation of a / $\mathrm{x}$-ions from $\mathrm{N}$-centered radicals is both energetically and kinetically favorable over side-chain cleavages and the formation of $a / x$-ions [53]. Our results demonstrate for the first time that the same radical-induced dissociation pathways are responsible for formation of a number of fragment ions in MS/MS spectra of peptide radical cations.

Even-electron $x$-ions can be formed either directly from the $\mathrm{M}^{+\cdot}$ precursor ion or from larger $\left[\mathrm{x}_{\mathrm{n}}+\mathrm{H}\right]^{+}$. ions through reaction 5 .

$$
\left[\mathrm{x}_{\mathrm{n}}+\mathrm{H}\right]^{+\cdot} \rightarrow \mathrm{x}_{\mathrm{n}-1}^{+}+\mathrm{CH}_{2} \mathrm{NHCO}
$$

However, the $\mathrm{x}_{4}^{+}$ion at $\mathrm{m} / \mathrm{z} 548.3$ (not labeled in the spectrum) is observed as a minor fragment in the $\mathrm{MS}^{4}$ spectrum of the $\left[\mathrm{x}_{5}+\mathrm{H}\right]^{+\cdot}$ ion of GVGIHPR ${ }^{+}$(Figure $3)$, suggesting that the even-electron $x$-ion is predominantly produced directly from the $\mathrm{M}^{+\cdot}$ precursor ion, while sequential fragmentation of larger odd-electron $x$-ions (reaction 5) has only a minor contribution to the formation of this product.

\section{Role of the Basic Residue}

As discussed earlier, $\alpha$-radical cations containing arginine residue produce almost identical MS/MS spectra. However, strikingly different fragmentation patterns were obtained for $\alpha$-radicals formed by the loss of the arginine side chain, $[\mathrm{M}-99]^{+.}$. For example, both side-chain losses and the formation of a-ions are completely suppressed in the spectrum of G $\mathrm{VYIHPF}^{+}$(Figure $4 \mathrm{a})$ corresponding to the $[\mathrm{M}-99]^{+\cdot} \alpha$-radical of RVYIHPF. In contrast, the spectrum of $\mathrm{GVYIHPF}^{+}$is dominated by several abundant backbone fragments, including even-electron y-ions and an odd-electron $\left[b_{5}-\mathrm{H}\right]^{+\cdot}$ ion. In addition, several minor product ions, including losses of 29 and 56 from isoleucine, $\left[b_{4}-\right.$ $\mathrm{H}]^{+*},\left[\mathrm{a}_{5}-\mathrm{H}\right]^{+\cdot}, \mathrm{z}_{4}^{+}, \mathrm{z}_{5}^{+\cdot}$, and internal YIH fragment (not labeled in the figure) are observed.

Similar results were obtained for $\alpha$-radicals of Tyr ${ }^{8}-$ Substance P (Figure 5). Specifically, there is a significant difference between dissociation pathways of the GPKPQQFYGLM-NH ${ }_{2} \alpha$-radical produced by the loss of the arginine side chain and other $\alpha$-radical cations of $\mathrm{Tyr}^{8}$-Substance P. While most of the characteristic fragments of radical-induced dissociation are retained in the CID spectrum of the $[\mathrm{M}-99]^{+\cdot}$ ion, it also contains a number of additional features, including $\mathrm{y}_{9}^{+}$, loss of $\mathrm{NH}_{3}$, abundant $\mathrm{y}_{\mathrm{n}}^{*}$ ions (i.e., $\mathrm{y}_{\mathrm{n}}-\mathrm{NH}_{3}$ ), and internal

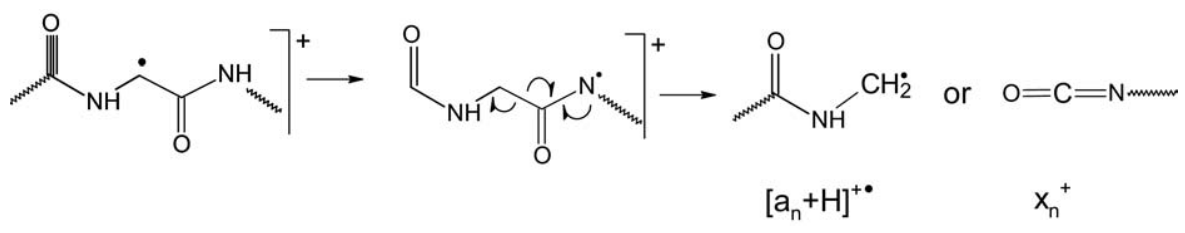

Scheme 4 
fragment ions. All additional peaks in the spectrum of the $[\mathrm{M}-99]^{+\cdot}$ ion are also present in the CID spectrum of the protonated $\mathrm{Tyr}^{8}$-Substance P (Figure 6a), suggesting that charge-driven fragmentation is responsible for the formation of these fragment ions.

Our recent study demonstrated that two distinct families of structures of the radical cation of RVYIHPF are formed during gas-phase fragmentation of $\mathrm{Co}^{\mathrm{II}}$ (salen)peptide complex [49] corresponding to the canonical form and the zwitterionic form of the radical cation, in which the tyrosine side chain is deprotonated and the basic arginine side chain is protonated. Efficient deprotonation of the tyrosine residue upon oxidation is attributed to a dramatic increase in the acidity of the phenolic hydrogen. The $\mathrm{pK}_{\mathrm{a}}$-value for tyrosine changes from 10 for the neutral molecule to $\mathrm{pK}_{\mathrm{a}}=-2$ for the radical [54]. Facile formation of a-ions is typically observed for peptide radicals containing a basic amino acid residue close to the $\mathrm{N}$-terminus [41, 42, 45]. In addition, $\mathrm{C}_{\alpha}-\mathrm{C}$ bond cleavages have been reported for peptide radicals of arginine-containing peptides produced via homolytic bond cleavages of radical initiator groups attached to the $\mathrm{N}$-terminus [27] or side chains of the protonated peptide [30] induced by collisions or photon absorption. Radical cations produced using these approaches are most likely protonated at the basic arginine residue. Our previous studies demonstrated
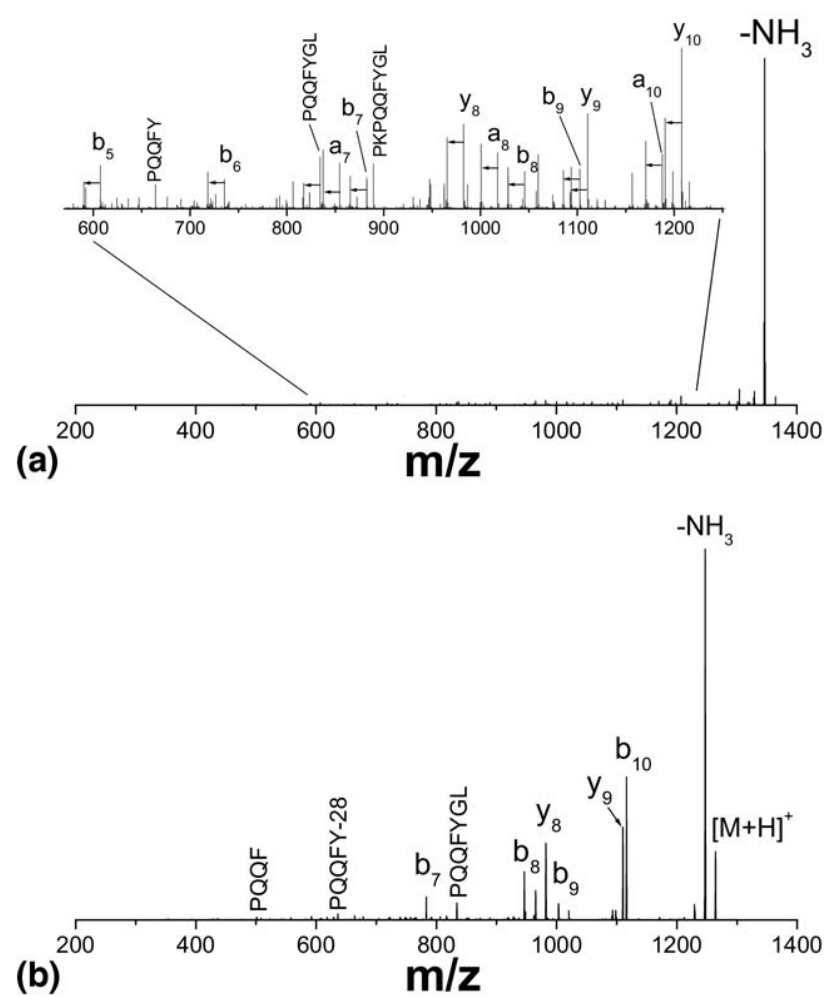

Figure 6. (a) LTQ/Orbitrap MS/MS spectrum of the singly protonated $\mathrm{Tyr}^{8}$-Substance P (RPKPQQFYGLM-NH ${ }_{2}$ ). Horizontal arrows indicate losses of $\mathrm{NH}_{3}$ from different backbone fragments; (b) ion trap MS/MS spectrum of the singly protonated GPKPQQFYGLM-NH that proton-driven fragmentation of protonated angiotensin III analogs is associated with higher energy barrier and is kinetically slower than radical-driven fragmentation of the corresponding radical cations [49, 55]. Because in arginine-containing peptide radical cations the proton is sequestered at the basic residue, radical-induced dissociation pathways are energetically more favorable processes resulting in distinctly different fragmentation behavior of radical cations as compared to protonated peptides [49]. Loss of the arginine side-chain $\left(\mathrm{C}_{4} \mathrm{H}_{9} \mathrm{~N}_{3}\right)$ resulting in formation of the [M $99]^{+\cdot} \alpha$-radical cation eliminates the basic site that can sequester the proton. Formation of abundant y-ions and $\left[b_{5}-\mathrm{H}\right]^{+\cdot}$ fragment from the $[\mathrm{M}-99]^{+\cdot}$ precursor indicates that the available proton is mobile and directs fragmentation of the $[\mathrm{G} \text { VYIHPF }]^{+}$radical cation. Our results indicate that while dissociation of argininecontaining $\alpha$-radical cations of angiotensin III is dominated by radical-induced cleavages, alternative lowenergy pathways involving mobile proton become available following the loss of the basic side chain.

Figure 4 compares fragmentation behavior of the $\left[\mathrm{GVYIHPF}^{+} \alpha\right.$-radical and the [GVYIHPF] $^{+\cdot}$ radical cation produced through reaction 1 is Scheme 2 . In this ion the radical is most likely originally localized on the tyrosine side chain [25]. In addition to proton-driven backbone cleavages observed for the [GVYIHPF] ${ }^{+}$ $\alpha$-radical fragmentation spectrum of [GVYIHPF] ${ }^{+\cdot}$ also contains an abundant $[\mathrm{M}-106]^{+\cdot}$ product ion characteristic of the radical-driven fragmentation. Recently we demonstrated that facile loss of the tyrosine side chain occurs from distonic structures, in which radical site is delocalized over the phenol ring of the tyrosine side chain [49]. Such structures are formed through fast transfer of phenolic proton to a more basic site following ionization. DFT calculations showed that the barrier for the 106 loss is only $19 \mathrm{kcal} / \mathrm{mol}$ for the deprotonated tyrosine side chain and is close to $58 \mathrm{kcal} / \mathrm{mol}$ for the neutral side chain [49]. Abundant loss of 106 from [GVYIHPF] $^{+\cdot}$ suggests that a significant number of conformers of this ion contain deprotonated tyrosyl radical. In contrast, loss of 106 is not observed for the isomeric [G $\mathrm{VYIHPF}]^{+} \alpha$-radical, indicating that this ion contains the neutral tyrosine side chain for which this dissociation pathway is energetically more demanding. Our results demonstrate that while radical-driven fragmentation is commonly suppressed as a result of the loss of the arginine side chain, energetically and kinetically favorable radical-driven fragmentation pathways can still effectively compete with the charge-driven dissociation.

\section{Formation of $y_{n-1}^{+}$Ions}

Formation of y-ions resulting from cleavage of the first amide bond, $\mathrm{y}_{\mathrm{n}-1}^{+}$, is commonly observed in CID spectra of peptide radical cations. For example, abundant $\mathrm{y}_{8}^{+}$ ion is observed for the FRWGKPVGY precursor (Figure S1), $\mathrm{y}_{6}^{+}$fragment is present in spectra shown in Figure 2, 
while spectra of the $\mathrm{M}^{+}$ion and $\alpha$-radicals of $\mathrm{Tyr}^{8}$ Substance P (RPKPQQFYGLM-NH ${ }_{2}$ ) contain an abundant $y_{10}^{+}$fragment (Figure 5). Formation of this fragment from Tyr $^{8}$-Substance $\mathrm{P}$ could be attributed to selective cleavage $\mathrm{N}$-terminal to the proline residue. Enhanced cleavage $\mathrm{N}$-terminal to proline with preferential formation of $y$-ions - the so called "proline effect" - is commonly observed in MS/MS spectra of protonated peptides and proteins [56-59]. However, the $\mathrm{y}_{10}^{+}$product ion is not observed in the spectrum of the protonated GPKPQQFYGLM-NH $\mathrm{N}_{2}$ shown in Figure $6 \mathrm{~b}$, indicating that the formation of this fragment from the radical cation is not facilitated by the "mobile proton."

In contrast, cleavage at the second proline residue of $\mathrm{Tyr}^{8}$-Substance $\mathrm{P}$ resulting in formation of the $\mathrm{y}_{8}^{+}$ion is dramatically enhanced in the absence of the basic arginine side-chain suggesting that formation of this product ion is driven by the available proton. The $\mathrm{y}_{8}^{+}$ ion is observed as a minor fragment in the spectrum of the $\mathrm{M}^{+\cdot}$ precursor ion (Figure 5a) and as a major product of the $[\mathrm{M}-99]^{+\cdot} \alpha$-radical but not from other $\alpha$-radicals of $\mathrm{Tyr}^{8}$-Substance P. It is reasonable to assume that the $\mathrm{y}_{8}^{+}$fragment of the radical cation of Tyr $r^{8}$-Substance $\mathrm{P}$ is formed through sequential proton-driven fragmentation of the primary [M 99] ${ }^{+\cdot}$ product ion.

Similar behavior was observed for $\mathrm{y}_{7}^{+}$and $\mathrm{y}_{8}^{+}$products of the FRWGKPVGY precursor ion (Figure S1). The $\mathrm{y}_{8}^{+}$ion, the most abundant fragment of the radical cation, is only a minor product of the protonated species, while the enhanced formation of the $y_{7}^{+}$ion is observed in the absence of the arginine residue. From the above discussion it follows that loss of one $\mathrm{N}$ terminal amino acid residue form peptide radical cations resulting in formation of $\mathrm{y}_{\mathrm{n}-1}^{+}$fragment often follows radical-directed pathways. The mechanism rationalizing formation of abundant $\mathrm{y}_{\mathrm{n}-1}^{+}$ions is shown in Scheme 5. This mechanism, proposed by $\mathrm{O}^{\prime} \mathrm{Hair}$ and coworkers [36], involves the N-terminal $\alpha$-radical, in which the $\alpha$-carbon radical is stabilized by the presence of a strong electron-donating $\mathrm{NH}_{2}$ group and an electronwithdrawing $\mathrm{CONH}$ group [60]. Radical stabilization energies (RSE) calculated for model peptide backbone radicals indicate that the $\mathrm{N}$-terminal $\alpha$-radical is generally significantly more stable than $\alpha$-radicals located on inner residues. For example, RSE of the $\mathrm{NH}_{2}-\mathrm{CH}$ $\mathrm{C}(\mathrm{O}) \mathrm{NH}_{2}$ model of the $\mathrm{N}$-terminal peptide radical is ca. $15 \mathrm{~kJ} / \mathrm{mol}$ higher than RSE of the $\mathrm{HC}(\mathrm{O}) \mathrm{NH}-\mathrm{CH}$ $\mathrm{C}(\mathrm{O}) \mathrm{NH}_{2}$ radical that mimics other $\alpha$-radical locations on peptide backbone [60]. O'Hair and coworkers dem-

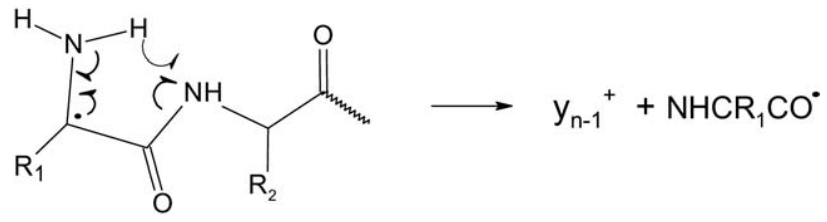

Scheme 5 onstrated that $\mathrm{y}_{2}^{+}$fragments of $\mathrm{GXR}^{+\cdot}$ precursor ions are produced via radical-driven fragmentation of the $\mathrm{N}$ terminal $\alpha$-radical [36].

Our results indicate that a similar mechanism is responsible for the formation of $\mathrm{y}_{\mathrm{n}-1}^{+}$fragments from more complex peptide radical cations. While $\mathrm{y}_{\mathrm{n}-1}^{+}$fragments can be also formed through proton-driven pathways, comparison of MS/MS spectra of $[\mathrm{M}+\mathrm{H}]^{+}$and $\mathrm{M}^{+\cdot}$ ions can be readily used to distinguish between $\mathrm{y}_{\mathrm{n}-1}^{+}$fragment ions produced through charge-directed and radical-driven fragmentation. From the above discussion, it follows that radical-driven formation of $\mathrm{y}_{\mathrm{n}-1}^{+}$ fragments from $\mathrm{M}^{+\cdot}$ precursor ions can be used as a marker of $\mathrm{N}$-terminal $\alpha$-radical isomers.

\section{Conclusions}

In this study, we compared fragmentation behavior of $\alpha$-radical cations of several arginine-containing peptides of different size and complexity. We found that in the presence of the basic residue fragmentation patterns obtained for different $\alpha$-radical cations of the same radical precursor are strikingly similar. Our results suggest that in these systems the radical sites are mobile and that the ions do not retain the memory of the initial radical location. In contrast, fragmentation of various isomers of $\mathrm{GG}^{+\cdot}$ [39] and $\mathrm{GGG}^{+\cdot}$ [40] radical cations strongly depend on the initial location of the radical. $\mathrm{Chu}$ et al. demonstrated that isomers of $\mathrm{GGG}^{+\cdot}$ are separated by high isomerization barriers, and that for this simple model system fragmentation efficiently competes with isomerization. The difference between fast radical scrambling observed in this study and much slower isomerization reported for the GGG radical cation could be rationalized assuming that hydrogen atoms of amino acid side chains facilitate the radical scrambling [41].

Fragmentation of peptide radical cations with the $\mathrm{N}$-terminal arginine shows abundant formation of aions through $\mathrm{C}_{\alpha}-\mathrm{C}$ bond cleavages. While the formation of even-electron a-ions from peptide radical cations has been previously discussed, the formation of oddelectron $\left[x_{n}+H\right]^{+\cdot}$ products formed via the same pathway has not been explored in any detail. It has been suggested that odd-electron $x$-ions are extremely unstable and, once formed, immediately fragment to yield smaller $x$ - and $z$-ions. In this study, we observed the formation of $\left[x_{n}+H\right]^{+\cdot}$ fragments from a number of peptide radicals with the $\mathrm{C}$-terminal arginine residue. $[\mathrm{x}+\mathrm{H}]$-ions undergo a number of side-chain losses typical for all peptide radical cations and backbone fragmentation resulting in formation of smaller $z$ - and $\mathrm{x}$-ions. Loss of NHCO (reaction 3) was observed as a minor dissociation channel. The enhanced formation of z-ions at tyrosine and valine was observed for a number of peptide radicals regardless of the presence and position of the basic amino acid residue. The mechanism proposed by Siu and coworkers [46] is most likely 
responsible for the formation of a number of z-ions from large peptide radical cations.

Dissociation of arginine-containing peptide radicals is dominated by radical-driven processes. In contrast, fragmentation of relatively small $\alpha$-radicals produced by the loss of the arginine side chain is dominated by charge-directed amide bond cleavages. Ionization of peptide molecules often results in formation of zwitterionic structures, in which the proton is moved from an acidic site to the basic arginine side chain. Because arginine sequesters the proton, charge-directed dissociation pathways in arginine-containing peptide radicals are strongly suppressed. Loss of the basic arginine side chain releases the "mobile proton" making chargedirected fragmentation energetically and kinetically more favorable. In the absence of the arginine residue, radical-driven fragmentation is almost completely suppressed for relatively small peptide radicals but becomes much more pronounced for larger peptides. Future studies will address in greater detail the competition between charge-driven and radical-driven fragmentation of peptide radicals.

Charge-directed fragmentation of $\mathrm{M}^{+\cdot}$ ions is characterized by cleavages of amide bonds resulting in formation of $y$ - and $[\mathrm{b}-\mathrm{H}]$-ions. An interesting exception is the radical-induced loss of the $\mathrm{N}$-terminal amino acid residue resulting in formation of the $\mathrm{y}_{\mathrm{n}-1}^{+}$fragment ion. This pathway most likely involves captodatively stabilized $\mathrm{N}$-terminal $\alpha$-radical precursors. Although $\mathrm{y}_{\mathrm{n}-1}^{+}$ions can also be formed through charge-directed fragmentation, comparison between dissociation patterns of $[\mathrm{M}+\mathrm{H}]^{+}$ and $\mathrm{M}^{+\cdot}$ ions can be used to determine the presence of $\mathrm{N}$-terminal $\alpha$-radical structures that are otherwise difficult to distinguish.

\section{Acknowledgments}

The authors acknowledge partial support for this study by a grant from the Chemical Sciences Division, Office of Basic Energy Sciences of the US DOE and partially by the University of Hong Kong and Hong Kong Research Grant Council, Special Administrative Region, China (project nos. 7018/06P and 7012/08P). The research described in this manuscript was performed at the W. R. Wiley Environmental Molecular Sciences Laboratory (EMSL), a national scientific user facility sponsored by the U.S. Department of Energy's Office of Biological and Environmental Research and located at Pacific Northwest National Laboratory (PNNL). PNNL is operated by Battelle for the U.S. Department of Energy. I.K.C. acknowledges participation in the PNNL Interfacial and Condensed Phase Summer Research Institute.

\section{Appendix A Supplementary Material}

Supplementary material associated with this article may be found in the online version at doi:10.1016/ j.jasms.2009.12.021.

\section{References}

1. Zubarev, R. A.; Kelleher, N. L.; McLafferty, F. W. Electron Capture Dissociation of Multiply Charged Protein Cations. A Nonergodic Process. J. Am. Chem. Soc. 1998, 120, 3265-3266.

2. Zubarev, R. A. Reactions of Polypeptide Ions with Electrons in the Gas Phase. Mass Spectrom. Rev. 2003, 22, 57-77.

3. Syka, J. E. P.; Coon, J. J.; Schroeder, M. J.; Shabanowitz, J.; Hunt, D. F. Peptide and Protein Sequence Analysis by Electron Transfer Dissociation Mass Spectrometry. Proc. Natl. Acad. Sci. U.S.A. 2004, 101, 95289533.

4. Cooper, H. J.; Hakansson, K.; Marshall, A. G. The Role of Electron Capture Dissociation in Biomolecular Analysis. Mass Spectrom. Rev. 2005, 24, 201-222.

5. Zubarev, R. A. Electron Capture Dissociation and Other Ion-Electron Fragmentation Reactions. In Principles of Mass Spectrometry Applied to Biomolecules; Laskin, J.; Lifshitz C.; Eds.; John Wiley and Sons: New York, 2006; pp 475-517.

6. Breuker, K. Protein Structure and Folding in the Gas Phase: Uniquitin and Cytochrome $c$. In Principles of Mass Spectrometry Applied to Biomolecules; Laskin, J.; Lifshitz, C.; Eds.; John Wiley and Sons., Inc.: Hoboken, NJ, 2006; pp 177-212.

7. Hopkinson, A. C.; Siu, K. W. M., Peptide Radical Cations. In Principles of Mass Spectrometry Applied to Biomolecules; Laskin, J.; Lifshitz, C.; Eds.; John Wiley and Sons., Inc.: Hoboken, NJ. 2006; pp 301-335.

8. Gunawardena, H. P.; He, M.; Chrisman, P. A.; Pitteri, S. J.; Hogan, J. M.; Hodges, B. D. M.; McLuckey, S. A. Electron Transfer Versus Proton Transfer in Gas-Phase Ion/Ion Reactions of Polyprotonated Peptides. J. Am. Chem. Soc. 2005, 127, 12627-12639.

9. Turecek, F.; Chen, X. H.; Hao, C. T. Where Does the Electron Go? Electron Distribution and Reactivity of Peptide Cation Radicals Formed by Electron Transfer in the Gas Phase. J. Am. Chem. Soc. 2008, 130, $8818-8833$.

10. Kjeldsen, F.; Silivra, O. A.; Ivonin, I. A.; Haselmann, K. F.; Gorshkov, M.; Zubarev, R. A. C $\alpha$-C Backbone Fragmentation Dominates in Electron Detachment Dissociation of Gas-Phase Polypeptide Polyanions. Chem. Eur. J. 2005, 11, 1803-1812.

11. Antoine, R.; Joly, L.; Tabarin, T.; Broyer, M.; Dugourd, P.; Lemoine, J. Photo-Induced Formation of Radical Anion Peptides. Electron Photodetachment Dissociation Experiments. Rapid Commun. Mass Spectrom. 2007, 21, 265-268.

12. Pingitore, F.; Wesdemiotis, C. Characterization of Dipeptide Isomers by Tandem Mass Spectrometry of Their Mono- Versus Dilithiated Complexes. Anal. Chem. 2005, 77, 1796-1806.

13. Hu, P. F.; Loo, J. A. Gas-Phase Coordination Properties of $\mathrm{Zn} 2+, \mathrm{Cu} 2+$ $\mathrm{Ni} 2+$, and $\mathrm{Co} 2+$ with Histidine-Containing Peptides. J. Am. Chem. Soc. 1995, 117, 11314-11319.

14. Gatlin, C. L.; Rao, R. D.; Turecek, F.; Vaisar, T. Carboxylate and Amine Terminus Directed Fragmentations in Gaseous Dipeptide Complexes with Copper(II) and Diimine Ligands Formed by Electrospray. Anal. Chem. 1996, 68, 263-270.

15. Boutin, M.; Bich, C.; Afonso, C.; Fournier, F.; Tabet, J. C. NegativeCharge Driven Fragmentations for Evidencing Zwitterionic Forms from Doubly Charged Coppered Peptides. J. Mass Spectrom. 2007, 42, 25-35.

16. Turecek, F. Copper-Biomolecule Complexes in the Gas Phase. The Ternary Way. Mass Spectrom. Rev. 2007, 26, 563-582.

17. Chu, I. K.; Rodriquez, C. F.; Lau, T. C.; Hopkinson, A. C.; Siu, K. W. M. Molecular Radical Cations of Oligopeptides. J. Phys. Chem. B 2000, 104, 3393-3397.

18. Chu, I. K.; Rodriguez, C. F.; Rodriguez, F.; Hopkinson, A. C.; Siu, K. W. M. Formation of Molecular Radical Cations of Enkephalin Derivatives Via Collision-Induced Dissociation of ElectrosprayGenerated Copper (II) Complex Ions of Amines and Peptides. J. Am. Soc. Mass Spectrom. 2001, 12, 1114-1119.

19. Bagheri-Majdi, E.; Ke, Y. Y.; Orlova, G.; Chu, I. K.; Hopkinson, A. C.; Siu, K. W. M. Copper-Mediated Peptide Radical Ions in the Gas Phase. J. Phys. Chem. B 2004, 108, 11170-11181.

20. Chu, I. K.; Siu, S. O.; Lam, C. N. W.; Chan, J. C. Y.; Rodriquez, C. F. Formation of Molecular Radical Cations of Aliphatic Tripeptides from Their Complexes with Cu-II(12-Crown-4). Rapid Commun. Mass Spectrom. 2004, 18, 1798-1802.

21. Lam, C. N. W.; Ruan, E. D. L.; Ma, C. Y.; Chu, I. K. Non-Zwitterionic Structures of Aliphatic-Only Peptides Mediated the Formation and Dissociation of Gas Phase Radical Cations. J. Mass Spectrom. 2006, 41, 931-938.

22. Barlow, C. K.; Wee, S.; McFadyen, W. D.; O'Hair, R. A. J. Designing Copper(II) Ternary Complexes to Generate Radical Cations of Peptides in the Gas Phase: Role of the Auxiliary Ligand. J. Chem. Soc. Dalton Trans. 2004, 20, 3199-3204.

23. Barlow, C. K.; McFadyen, W. D. ; O'Hair, R. A. J. Formation of Cationic Peptide Radicals by Gas-Phase Redox Reactions with Trivalent Chromium, Manganese, Iron, and Cobalt Complexes. J. Am. Chem. Soc. 2005, $127,6109-6115$.

24. Ke, Y.; Zhao, J.; Verkerk, U. H.; Hopkinson, A. C.; Siu, K. W. M. Histidine, Lysine, and Arginine Radical Cations: Isomer Control Via the Choice of Auxiliary Ligand (L) in the Dissociation of [Cu-II(L)(Amino Acid)](·2+) Complexes. J. Phys. Chem. B 2007, 111, 14318-14328. 
25. Laskin, J.; Yang, Z.; Chu, I. K. Energetics and Dynamics of Electron Transfer and Proton Transfer in Dissociation of MetalIII(Salen)-Peptide Complexes in the Gas Phase. J. Am. Chem. Soc. 2008, 130, 3218-3230.

26. Masterson, D. S.; Yin, H. Y.; Chacon, A.; Hachey, D. L.; Norris, J. L.; Porter, N. A. Lysine Peroxycarbamates: Free Radical-Promoted Peptide Cleavage. J. Am. Chem. Soc. 2004, 126, 720-721.

27. Hodyss, R.; Cox, H. A.; Beauchamp, J. L. Bioconjugates for Tunable Peptide Fragmentation: Free Radical Initiated Peptide Sequencing (FRIPS). J. Am. Chem. Soc. 2005, 127, 12436-12437.

28. Hao, G.; Gross, S. S. Electrospray Tandem Mass Spectrometry Analysis of S- and N-Nitrosopeptides: Facile Loss of NO and Radical-Induced Fragmentation. J. Am. Soc. Mass Spectrom. 2006, 17, 1725-1730.

29. Wee, S.; Mortimer, A.; Moran, D.; Wright, A.; Barlow, C. K.; O'Hair, R. A. J.; Radom, L.; Easton, C. J. Gas-Phase Regiocontrolled Generation of Charged Amino Acid and Peptide Radicals. Chem. Commun. 2006, 40, 4233-4235.

30. Ly, T.; Julian, R. R. Tracking Radical Migration in Large Hydrogen Deficient Peptides with Covalent Labels: Facile Movement Does Not Equal Indiscriminate Fragmentation. J. Am. Soc. Mass Spectrom. 2009, 20, 1148-1158.

31. Ly, T.; Julian, R. R. Residue-Specific Radical-Directed Dissociation of Whole Proteins in the Gas Phase. I. Am. Chem Soc. 2008, 130, 351-358.

32. Thompson, M. S.; Cui, W. D.; Reilly, J. P. Fragmentation of Singly Charged Peptide ions by Photodissociation at $\lambda=157 \mathrm{~nm}$. Angew. Chem. Int. Ed. 2004, 43, 4791-4794.

33. Ly, T.; Julian, R. R. Ultraviolet Photodissociation: Developments towards Applications for Mass-Spectrometry-Based Proteomics. Angew. Chem. Int. Ed. 2009, 48, 7130-7137.

34. Hopkinson, A. C. Radical Cations of Amino Acids and Peptides: Structures and Stabilities. Mass Spectrom. Rev. 2009, 28, 655-671.

35. Wee, S.; O'Hair, R. A. J.; McFadyen, W. D. Comparing the Gas-Phase Fragmentation Reactions of Protonated and Radical Cations of the Tripeptides GXR. Int. J. Mass Spectrom. 2004, 234, 101-122.

36. Wee, S.; O'Hair, R. A. J.; McFadyen, W. D. The Role of the Position of the Basic Residue in the Generation and Fragmentation of Peptide Radical Cations. Int. J. Mass Spectrom. 2006, 249, 171-183.

37. Moran, D.; Jacob, R.; Wood, G. P. F.; Coote, M. L.; Davies, M. J.; O'Hair, R. A. J.; Easton, C. J.; Radom, L. Rearrangements in Model Peptide-Type Radicals Via Intramolecular Hydrogen-Atom Transfer. Helv. Chim. Acta 2006, 89, 2254-2272.

38. Leymarie, N.; Costello, C. E.; O'Connor, P. B. Electron Capture Dissociation Initiates a Free Radical Reaction Cascade. J. Am. Chem. Soc. 2003, $125,8949-8958$

39. Pingitore, F.; Bleiholder, C.; Paizs, B.; Wesdemiotis, C. Unimolecular Chemistry of Metal Ion-Coordinated $\alpha$-Dipeptide Radicals. Int. J. Mass Spectrom. 2007, 265, 251-260.

40. Chu, I. K.; Zhao, J.; Xu, M.; Siu, S. O.; Hopkinson, A. C.; Siu, K. W. M. Are the Radical Centers in Peptide Radical Cations Mobile? The Generation, Tautomerism, and Dissociation of Isomeric $\alpha$-CarbonCentered Triglycine Radical Cations in the Gas Phase. J. Am. Chem. Soc. 2008, 130, 7862-7872.

41. Sun, Q.; Nelson, H.; Ly, T.; Stoltz, B. M.; Julian, R. R. Chain Chemistry Mediates Backbone Fragmentation in Hydrogen Deficient Peptide Radicals. J. Prot. Res. 2009, 8, 958-966.

42. Zhang, L.; Reilly, J. P. Radical-Driven Dissociation of Odd-Electron Peptide Radical Ions Produced in $157 \mathrm{~nm}$ Photodissociation. J. Am. Soc. Mass Spectrom. 2009, 20, 1378-1390.
43. Laskin, J.; Futrell, J. H.; Chu, I. K. Is Dissociation of Peptide Radical Cations an Ergodic Process? J. Am. Chem. Soc. 2007, 129, 9598-9599.

44. Laskin, J. Energy and Entropy Effects in Gas-Phase Dissociation of Peptides and Proteins. In Principles of Mass Spectrometry Applied to Biomolecules; Laskin, J.; Lifshitz, C.; Eds.; John Wiley and Sons., Inc.: Hoboken, NJ, 2006.

45. Laskin, J.; Yang, Z. B.; Lam, C.; Chu, I. K. Charge-Remote Fragmentation of Odd-Electron Peptide Ions. Anal. Chem. 2007, 79, 6607-6614

46. Siu, C. K.; Ke, Y.; Orlova, G.; Hopkinson, A. C.; Siu, K. W. M. Dissociation of the N-C- $\alpha$ Bond and Competitive Formation of the $[\mathrm{z}(\mathrm{n})-\mathrm{H}]$ $(\cdot+)$ and $[\mathrm{c}(\mathrm{n})+2 \mathrm{H}](+)$ Product Ions in Radical Peptide Ions Containing Tyrosine and Tryptophan: The Influence of Proton Affinities on Product Formation. J. Am. Soc. Mass Spectrom. 2008, 19, 1799-1807.

47. Varkey, S. P.; Ratnasamy, C.; Ratnasamy, P. Zeolite-Encapsulated Manganese(III)Salen Complexes. J. Mol. Catal. A Chem. 1998, 135 295-306.

48. Wang, P.; Ohanessian, G.; Wesdemiotis, C. Cu(II)-Catalyzed Reaction in Ternary $[\mathrm{Cu}(\mathrm{AA})(\mathrm{AA}-\mathrm{H})](+)$ Complexes $(\mathrm{AA}=$ Gly, Ala, Val, Leu, Ile, t-Leu, Phe). Eur. J. Mass Spectrom. 2009, 15, 325-335.

49. Yang, Z. B.; Lam, C.; Chu, I. K.; Laskin, J. The Effect of the Secondary Structure on Dissociation of Peptide Radical Cations: Fragmentation of Angiotensin III and Its Analogues. J. Phys. Chem. B 2008, 112, $12468-$ 12478.

50. Johnson, R. S.; Martin, S. A.; Biemann, K. Collision-Induced Fragmentation of $(\mathrm{M}+\mathrm{H})^{+}$ions of peptides. Side-Chain-Specific Sequence Ions. Int. J. Mass Spectrom. Ion Processes 1988, 86, 137-154.

51. Chu, I. K.; Lam, C. N. W. Generation of Peptide Radical Dications Via Low-Energy Collision-Induced Dissociation of $\left[\mathrm{Cu}^{\mathrm{II}}(\text { terpy })(\mathrm{M}+\mathrm{H})\right]^{3+}$. J. Am. Soc. Mass Spectrom. 2005, 16, 1795-1804.

52. Han, H.; Xia, Y.; McLuckey, S. A. Ion Trap Collisional Activation of c and $z$ Ions Formed Via Gas-Phase Ion/Ion Electron-Transfer Dissociation. I. Proteome Res. 2007, 6, 3062-3069.

53. Anusiewicz, I.; Jasionowski, M.; Skurski, P.; Simons, J. Backbone and Side-Chain Cleavages in Electron Detachment Dissociation (EDD). J. Phys. Chem. A 2005, 109, 11332-11337.

54. Huynh, M. H. V.; Meyer, T. J. Proton-Coupled Electron Transfer. Chem. Rev. 2007, 107, 5004-5064.

55. Laskin, J.; Bailey, T. H.; Futrell, J. H. Fragmentation Energetics for Angiotensin II and Its Analogs from Time-and Energy-Resolved Surface-Induced Dissociation Studies. Int. J. Mass Spectrom. 2004, 234, 89-99.

56. Hunt, D. F.; Yates, J. R.; Shabanowitz, J.; Winston, S.; Hauer, C. R. Protein Sequencing by Tandem Mass Spectrometry. Proc. Natl. Acad. Sci. U.S.A. 1986, 83, 6233-6237.

57. Schwartz, B. L.; Bursey, M. M. Some Proline Substituent Effects in the Tandem Mass-Spectrum of Protonated Penta-Alanine. Biol. Mass Spectrom. 1992, 21, 92-96.

58. Loo, J. A.; Edmonds, C. G.; Smith, R. D. Tandem Mass Spectrometry of Very Large Molecules. 2. Dissociation of Multiply Charged ProlineContaining Proteins from Electrospray Ionization. Anal. Chem. 1993, 65, 425-438.

59. Breci, L. A.; Tabb, D. L.; Yates, J. R.; Wysocki, V. H. Cleavage N-Terminal to Proline: Analysis of a Database of Peptide Tandem Mass Spectra. Anal. Chem. 2003, 75, 1963-1971.

60. Wood, G. P. F.; Moran, D.; Jacob, R.; Radom, L. Bond Dissociation Energies and Radical Stabilization Energies Associated with Model Peptide-Backbone Radicals. J. Phys. Chem. A 2005, 109, 6318-6325. 